\title{
Flouting Maxims Analysis of Conversation on Whatsapp Message
}

\author{
Widya Eka Septiani \\ STKIP PGRI Sidoarjo, email: widyaekaseptiani97@gmail.com \\ Agustin Wahyu Fatmawati \\ STKIP PGRI Sidoarjo
}

\begin{abstract}
The focus of this research is flouting maxim which is used by conversation on whatsapp message between Widya Eka Septiani and Edo Meggi Fernando as the students of English Education Study Program 2016. This research aims at: (1) describing the kinds of maxims flouted by conversation on whatsapp message between Widya Eka Septiani and Edo Meggi Fernando as the students of English Education Study Program 2016 and (2) revealing the reasons of flouting maxim showed by conversation on whatsapp message between Widya Eka Septiani and Edo Meggi Fernando as English Education'16. The research design of this study was descriptive qualitative research. The results of the research show that (1) the flouting maxims in conversation between Widya Eka Septiani and Edo Meggi Fernando by whatsapp message is flouting maxim of relation, and (2) revealing the reasons of flouting maxim showed by by conversation on whatsapp message between Widya Eka Septiani and Edo Meggi Fernando.
\end{abstract}

Keywords: flouting maxim, cooperative principle, reason of flouting maxim

\section{INTRODUCTION}

Language has risen to become a significant aspect of human existence. It is the manner in which people communicate and interact with one another. It is the content of what people say and what they intend to say during a conversation that is important. It is the means by which messages are communicated to others (Bloomer et al., 2005: 79). Language is inextricably linked to human existence because it serves as a means of communication. For example, according to Chaika (1982:1), "Language and society are so intertwined that it is impossible to understand one without understanding the other."

A wide variety of purposes are served by communication, specifically language. It is used for a variety of purposes including socializing, expressing feelings, sharing knowledge and ideas, maintaining positive relationships with others, and a variety of other activities related to human interaction throughout life. Conversation, which has grown to be the most commonly used form of human language, also serves a purpose as a component of language. 
In order to perform those functions effectively in a conversation, the participants in the conversation must adhere to a set of rules.

To be successful in communicating through conversation, two or more people as the participants of a conversation should be able to be cooperative each other so there is no misunderstanding in the conversation. The speaker can lead the listener to gain the messages in the conversation clearly and the listener can understand the meaning, even a hidden meaning, in the speaker's utterance. Grice (in Yule, 1996: 37) states that people have a successful conversation if they fulfill the Cooperative Principle that is elaborated in four subprinciples or maxims. The four maxims are maxim of quantity, quality, relevance, and manner. Those maxims make a conversation going smoothly and effectively to achieve its aims.

Understanding Cooperative Principle is not far from understanding conversation that is not fulfilling maxim. That is maxim flouting that becomes an interesting topic related to Cooperative Principle. By flouting maxims, people seem to be uncooperative, but actually, they do. They flouts of maxims because of some certain reasons. Behind the utterances in which maxim flouting occurs, there are some hidden meanings and certain purposes that is tried to be conveyed by the speaker.

A Cooperative principle was introduced by Grice (1975: 73), as stated by Grundy "Grice argued that speakers intends to be cooperative when they talk. One way of being cooperative for the speaker is to give as much information as is expected". The speaker wishes the conversation are good, relevant and clear, but naturally, people sometimes give the respons unpredictable. Cooperative principle is common rule to portray the participants how they cooperate in conversation to gain the efficient interaction (Levinson 1983: 101). It shows that cooperative principles have the rules that should be obeyed by the speaker and the hearer. The rules of cooperative principle are called conversational maxims. A conversational maxims are divided into four types: maxim of quality, maxim of quantity, maxim of relevant, and maxim of manner. Those maxims are important in daily conversation to avoid misunderstanding.

Grice were formulated maxims of Quantity, Quality, Relation and Manner as follows: 


\section{Quantity}

Maxim of quantity as one of the cooperative principle is chiefl y concerned with providing information as it is needed and that not giving the contribution more informative than it required. Therefore, each participant's contribution to conversation should be just as informative as it requires, it should not be less informative or more informative. And say as much as helpful but not more informative or less informative. Finnegan (2004, p.93) defi nes that in normal circumstance, speakers say just enough, that they supply no less information and no more than is necessary for the purpose of the communication, for example:

A : Could you tell me how to get to the market?

$B$ : next to that police offi ce.

It can be seen that B information is informative and give enough contribution toward A's question about the exact location of market.

\section{Quality}

The Maxim of Quality suggests that the speaker need to inform the fact in a conversation in order to create cooperative communication. Grice $(1975, \mathrm{p} .44)$ states that when we are held on conversation, the Maxim of Quality requires that we

1) Do not say what we consider to be fake.

2) Do not say something without having adequate and sufficient evidence.

For example:

\section{$A$ : Who is the current president of Indonesia?}

$B$ : Mr. Joko Widodo

Here, A gives the correct answer which proves about the proper and true fact

\section{Relation}

Maxims of relation recommend that the utterance must be relevant to the topic being conversed. Finegan (2004) states that this maxim expects speaker to deliver their utterance in such a way that is applicable and relevant to particular context being discussed: Be relevant at the time of the utterance. The maxim of relevance is fulfi lled when the speaker gives contribution that is relevant to the topic of preceding utterance. 
Therefore, Grundy (2000, p.74) says that each participant's need to contribute relevant utterance related to the subject of conversation, for example:

A : How about your holiday?
$B:$ Great and wonderful

\section{Manner}

Maxim of manner requires speaker's utterance to be understandable or comprehensible or not to be ambiguous, obscure, or disorderly and unnecessary prolixity. Thus, each participant's contribution needs to be plausibly direct, that is, it should not be blurred, ambiguous or excessively wordy. For example:

A : What's your opinion about the movie?

$B:$ Well the movie is amazing. The actors show their best performance.

The B's answer is following maxim of manner, B can answer the question from his partner about the movie clearly.

Once one of the maxims is violated by utterance generated by particular speaker, we need to assume that the speaker violated maxim is cooperative in communication. It can be said that violation is a indication that something being said indirectly. This is called flouting maxim. Grundy (2000, p.78) suggests that flouting maxims is a prominent way of getting an addressee to draw an inference, for example:

A : Can I borrow your laptop?

$B$ : Well, uh, I have so many assignment that need to be done.

From the example above, B's answer violated the maxim of Quantity, B does not supply as much information as A desired (whether he can borrow the laptop or not).

According to Brown and Yule (1989. p.32), flouting of maxim made by speaker expresses an additional meaning (contextual meaning) to his or her utterance. This occurrence is called conversational implicature. A speaker who does not follow the conversational maxims can be categorized to be flouting the maxims and consequently, conversational implicature is produced by the speaker. The addressee or hearer actually understands that the speaker has flouted the maxims so the addressee tries to infer further meaning from this violation of convention. 


\section{Flouting Maxim of Quality}

A: What is your name?

B: I'm the queen of Sheba

Implicature: B doesn't want to tell his or her name

B's statement is $\mathrm{fl}$ outing the maxim of quality because speaker B gives information which is not match with the actual fact but B still seems to be cooperative. B gives the untrue statement to B in order to make A to introspect that his statement is not correct. B's utterance suggests that A's is absurdly incorrect.

\section{Flouting Maxim of Quantity}

A $\mathrm{fl}$ out of maxim of quantity takes place when a speaker deliberately provides insuffi cient information within the situation requires. (Thomas, 1995)

$A$ : How are we getting there?

$B$ : we are getting there in Budi's car.

The statement above fl outs the maxim of quantity since the information does not give clear contribution and it is not informative as required. The statement above suggests that B doesn't want to have a travel with A.

\section{Flouting Maxim of Relation}

The maxim of relation is fl outed by making response which is very obvious irrelevant to the topic being discussed. (Thomas, 1995)

\section{A: Where will you go? \\ B: Out}

Implicature: B giving inappropriate response

B's utterance implicates that B doesn't want to answer A's question. B doesn't want to tell where exactly he or she wants to go.

\section{Flouting Maxim of Manner}

A: I think the government needs to make a policy for expatriate. Do you agree with me?

B: Well, I won't try to turn you away from your opinion

From the example above, it can be observed that the speaker B has been unsuccessful to monitor the maxim of manner by giving extremely long response for yes-no question posed by A. Actually, B just need to reply "yes" or "no". 
In fact, it is not easy for people to communicate spontaneously and say straight during the conversation. Cutting (2002: 40) emphasizes that Grice stated when the speaker does not obey the maxims, the speaker violates the maxim. There are some possibilities that people may break the rule of maxim: first, the speaker needs to give an additional information to make the hearer understand, second the speaker wants to give humor in their utterances and third the speaker hides something behind the conversation. Humor usually does not obey the rule of maxim. The speaker who give the humor in their conversation usually says another implied meaning behind the utterances.

When a teacher says, "Good morning, Anie." to her student who comes late, this teacher actually conveys a hidden message to the student. It is a kind of irony that says the opposite thing with the teacher really intends to say. As an example of maxim flouting, this situation is not fully completed since the student is not involved in the conversation directly. When someone asks, "How are you?" to another one and the other one answers by saying, "The weather is not good, it is so hot," it can be implied that the second speaker is flouting a maxim. Here, the 3 complete example is provided. The hidden meaning is either that the second person is not in a good condition or that the second person actually does not like the first person at that time. That is why the second speaker says that.

In maxim flouting, speakers perform some strategies in order to convey the hidden meanings of their utterances. They are also having reasons and certain purposes in being uncooperative. Everyone indeed has the possibility to flout the maxim of Cooperative Principle. Then, it can be assumed that whether the conversation is in the real life or even in a movie or in a novel that the script is made by people, maxim flouting can happen.

Flouting of maxims also happens in humor. Communicators imply that others' actions are not only unexpected, but unacceptable, and hence worthy of opposition in the form of discipline by laughter (Duncan, 1962 in Mayer 2000). Communication happens in many conditions, then humor is one of the part of communication which creates a funny occasion. According to Ross (1998: 1) humor is something that makes a person laugh or smile. It means humor consists of joke. A joker makes the audience laugh from ambiguous structure like phonology, graphology, morphology, lexis and syntax (Ross 1998: 8). Sometimes a humor happens when a person slips, it could not be hurt, but mostly people will laugh to know it. Humor can happen spontaneously or unspontaneosly. People who make a humor spontaneous, do an improvisation to make it funny. Someone who make a humor might be flouting the 
maxim. Hence, joker who play a humor does not pay attention to the utterance and it could be lot of flouting maxim. Flouting maxim can be found in drama, short story, movie, talkshow and stand-up comedy.

The example above shows how the speaker flout the maxim. From this background of this study, the researcher is interested to analysis the data and the research title is Flouting Maxims Analysis of Conversation on Whatsapp Message.

\section{METHOD}

The researchers are dealth with descriptive qualitative research. This research focus to identify the kinds of maxims are floated by the sender and receiver of whatsapp message and the reasons of floating maxim showed by conversation on whatsapp message between Widya Eka Septiani and Edo Meggi Fernando as the student of English Education 2016. The instrument is the whatsapp message. While, the object of this research is flouting maxim in conversation on whatsapp message between Widya Eka Septiani and Edo Meggi Fernando. The data are utterances used by the conversation on whatsapp message which contain the flouting of maxim in the dialogue. In analyzing the data, the research is using Grice theory (1975) to describe the maxim for describing the reason of floating maxim by using the theory of Chrisstoffersen in Tupan\&Natalia (2008).

\section{FINDING AND DISCUSSION}

The conversations which is conducted by Widya Eka Septiani and Edo Meggi Fernando on whatsapp message contain flouting maxim in it. In line with Grice (1975) which proposed four maxims, that is maxims of quantity, maxim of quality, maxims of relation, and maxims of manner, there are also flouting maxims for each maxims. Mostly, the conversation of Widya and Edo on whatsapp massage contain flouting maxims of relation. 
Looking the conversation on $24^{\text {th }}$ of April 2019 conducted by Widya Eka Septiani and Edo Meggi Fernando, flouting maxims of relation exist in it.

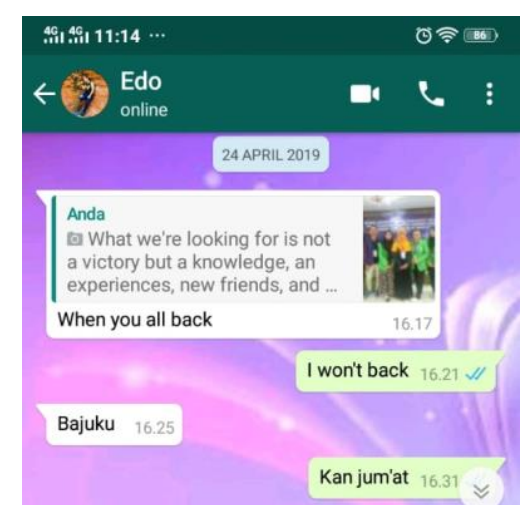

Figure 1. The first conversation

The picture contains the first conversation in this research which shows flouting maxims of relation. In this picture, Edo commented on Widya's status "when you all back". Then, Widya responded Edo's message “I won't back”. Shortly after, Edo sent a message "Bajuku”. Directly, Widya answered “Kan jum'at". From this short conversation, can be concluded that that is flouting maxims. In line with Thomas (1996), which stated that "the maxim of relation is exploited by making a response or observation which is very obviously irrelevant to the topic in hand". The speaker flouted the maxim of relation if his contribution is not relevant. Logically, there is no relation between "Bajuku" and "Kan jum'at". This conversation contains irrelevant contribution. But, this is particularized implicature where Edo and Widya understood well about the content what they are talking about. Thus, both Widya and Edo didn't feel difficulties when they did the conversation. While for the ones who read this conversation, they didn't know what they are talking about, because they didn't know the background knowledge of the context on the conversation.

The second conversation between Widya Eka Septiani and Edo Meggi Fernando which conducted on 18th of May 2019. The conversation which is started by Edo who commented Widya's status. Meanwhile, there is no relation between Edo's comment and Widya's status. 


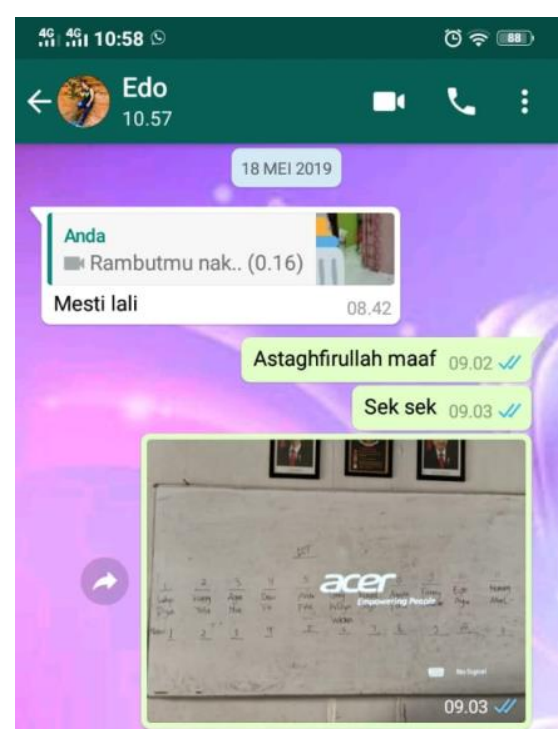

Figure 2. The Second Conversation

The conversation showed that even Edo didn't explain clearly what he meant, Widya still could understand what Edo's mean. When Edo sent a message "mesti lali", Widya responded "Astaghfirullah maaf". It means that Widya has done something mistaken or forgotten to Edo. Then, Widya sent a picture to Edo. Seems like the first picture, this conversation included in particularized implicature which is according to Grice (1989), it is occured when a conversation takes place in a very specific context in which locally recognized inferences are assumed.

It shows that Edo and Widya have understood about the context. They have the background knowledge before those conversation. This is proven by the previous conversation one day ago, on $17^{\text {th }}$ of May 2019.

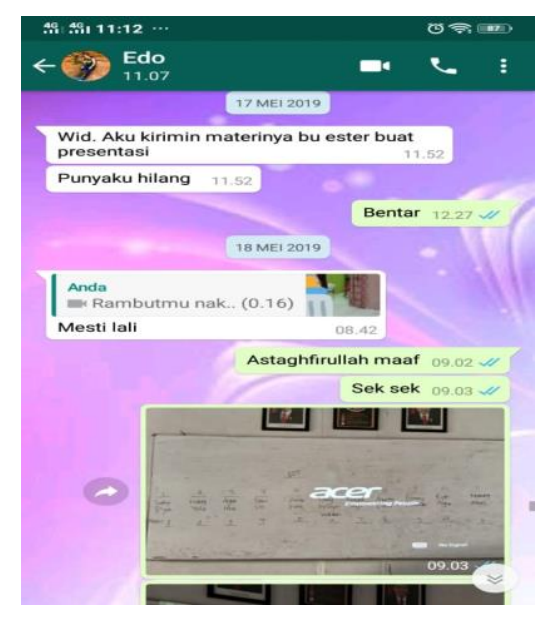

Figure 2. The Second Conversation 
It shows that before the conversation on $18^{\text {th }}$ of May 2019, Edo and Widya did a conversation. Edo asked Widya to send him one of subject material for a presentation, becouse his is lost. Then widya answerd "bentar", which meant that Widya will send the material. But, Widya did not send the material until tomorrow. Thus, when Edo commented Widya's status, Widya directly understood what Edo's mean. From those conversation, can be concluded that Widya forgot to send the material that Edo asked.

\section{CONCLUSION}

Flouting maxims is a prominent way of getting an addressee to draw an inference (Grundy , 2000, p.78). The researcher recommends for the next researchers to use Grice's theory as the basic theory to conduct the research and also other relevance theories to analyze different topic but still about maxim. Also, for further researchers, hopefully this research can be used as a reference to conduct another research about the flouting of maxim and the motivations of the characters flouted the maxim but using different movie script, or using the same movie script but in different aspects such as discussing maxim violation or else. The conversations which is conducted by Widya Eka Septiani and Edo Meggi Fernando on whatsapp message contain flouting maxim in it. In line with Grice (1975) which proposed four maxims, that is maxims of quantity, maxim of quality, maxims of relation, and maxims of manner, there are also flouting maxims for each maxims. Mostly, the conversation of Widya and Edo on whatsapp massage contain flouting maxims of relation.

\section{REFERENCES}

Bloomer, A. E. (2005). Introducing Language in use; A Coursebook. Oxon: Routledge.

Chaika, E. (1982). Language the Social Miror. Massachusets: Newbury House Publisher, Inc.

E.S, A. D. (2015). AN ANALYSIS OF FLOUTING MAXIM IN EFL CLASSROOM INTERACTION. Journal Vision, 2.

Grundy, P. (2000). Doing Pragmatics. London: Arnold, a member of the Hodder Headline.

Thomas, J. (1995). Meaning in Interaction: An Introduction to Pragmatics. USA: Pearson Education Limited.

Yule, G. (1996). Pragmatics. New York: Oxford University Press. 
Flouting Maxims Analysis of Conversation on Whatsapp Message

Zulfah Ibrahim, M. B. (2018). THE FLOUTING OF MAXIM IN THE SE7EN MOVIE SCRIPT. Jurnal Ilmu Budaya, 81-94. 